\title{
Oceanian Sovereignty: rethinking conservation in a sea of islands
}

\author{
Tamatoa Bambridge ${ }^{\mathrm{A}}$, Paul D'Arcy $^{\mathrm{B}}$ and Alexander Mawyer (iD) C,D \\ A EPHE-UPVD-CNRS, USR 3278 CRIOBE BP 1013 Papetoai, 98729 Moorea, French Polynesia. \\ ${ }^{B}$ Department of Pacific Affairs, Coral Bell School of Asia Pacific Affairs, College of Asia and the \\ Pacific, Australian National University, Canberra, ACT 0200, Australia. \\ ${ }^{C}$ Center for Pacific Islands Studies, School of Asian and Pacific Studies, University of Hawai ‘ $\mathrm{i}$ \\ at Mānoa, Honolulu, HI 96822, USA. \\ ${ }^{D}$ Corresponding author. Email: mawyer@hawaii.edu
}

\begin{abstract}
In an age of dramatic environmental and ecological challenges, the dynamics of sovereignty associated with the conservation of natural resources in Oceania are in flux. This article draws on the transformative work of Tongan anthropologist and political philosopher Epeli Hau'ofa to articulate characteristics of an Oceanian Sovereignty that illuminate ongoing conceptual shifts around conservation in this region. In the wake of intensifying and accelerating environmental challenges from global warming and other hazard drivers, understanding Indigenous peoples and local communities' deeply rooted and emerging perceptions and conceptions of rights over, responsibilities towards, and respect for, nature is a critical context for necessary transformations within conservation science, policy and practice. The articulation of sovereignty that we identify in Hau'ofa sheds light on how Oceania's peoples are asserting rights to make choices about the environmental futures of ocean and island spaces. Oceanian Sovereignty emphasises past, present and future obligations enacted though sustainable use in partnership with an ancestral ocean deeply embedded in cultural identity as a basis of governance rather than in legal and political arguments grounded in the constitutions of states. The resultant nature politics are exemplified in what we term tidal thinking. Tidal thinking refers to Indigenous and local peoples' fluid responses to current challenges around conservation and sustainable management of island and ocean futures and the linked wellbeing of human and non-human entities within them. We conclude with a number of conservation practice, governance, and policy implications that tidal thinking around Oceanian Sovereignty entails.
\end{abstract}

Keywords: conservation, Indigenous communities, Pacific Islands.

Received 3 March 2020, accepted 17 December 2020, published online 4 February 2021

\section{Locating an environmental and ecological sovereignty in Hau'ofa's Sea of Islands}

Beginning with 'Our Sea of Islands' (1994), the work of Tongan anthropologist Epeli Hau'ofa has inspired a generation of Pacific scholars and peoples. In this article we argue that neglected aspects of Hau'ofa's vision both anticipate and shed light on how Oceania's peoples are responding to the crisis of governance, management and conservation of regional natures in the era of climate change and rampant ecological and environmental degradation (Kelman 2017). The Pacific Islands region is notable for its biodiversity and functional ecological conservation potentials and precarities (Wittmer et al. 2018; Russell and Kueffer 2019). It is also notable for the ongoing struggles of Indigenous and local communities to re-exert agency over island and ocean environments that have for millennia been intimately linked to local identities and senses of place and belonging (Ruru 2008; D’Arcy 2009; Leenhardt et al. 2013). The persistence of such struggles are evident in both postcolonial and non-self-governing states. The challenge to conservation biologists, planners and policy makers of understanding and reconciling the social justice, environmental equity and everyday political implications of conservation decisions and practices is stark (Keppel et al. 2012; Mawyer and Jacka 2018; Bennett et al. 2019).

Conservation sciences are necessarily focused on the rehabilitation of ecosystems damaged by human activity, amelioration of current crises, and prevention of future loss. Notably, calls for greater inclusion of communities as intimately linked to, and inalienable from, their local environments are no longer limited to social scientists within the relevant literatures and practices. Both place-based (Pascua et al. 2017; Morishige et al. 2018) and largescale ecological assessments (Leong et al. 2019; Halpern 2020) now take human dimensions robustly into account. However, much existing work to interpolate Indigenous perspectives into environmental and conservation science has focused on the efficacy of Indigenous knowledge (McMillen et al. 2014; Lauer 2017), with a particularly strong focus on Indigenous senses of the sacred as a means of understanding human attachments to and practices of place and place-making (Berkes 2017; Dacks et al. 2019). We argue that understanding Indigenous peoples and local communities' deeply rooted and emerging perceptions, conceptions and enactments of rights over, responsibilities towards, and stewardship of, nature is a critical context for necessary transformations 
within conservation science, policy and practice both because of the potential for conflict when the rights and presences of Indigenous peoples and local communities are not taken into account (Alegado 2019; Aburto et al. 2020) and because of the potential for better meeting conservation goals across scales (Lyver et al. 2019).

As Indigenous and non-Indigenous scholars engaged with local conservation and Indigenous resource management, we suggest that Hau'ofa illuminates characteristics of sovereignty as conceived, perceived and practiced within Indigenous and local communities around environmental conservation and terrestrial and marine resource management in Oceania. We do so knowing that the relevance of sovereignty from the ground up, of sovereignty as experienced and enacted by Indigenous peoples and local communities across the region might otherwise be overlooked by conservation scientists or practitioners. The risk of conservation practitioners misperceiving the relevance of sovereignty to their work is particularly stark when their prior training or experience may have only located issues of sovereignty within the boundaries of legal or governance jurisdictions within a Westphalian model that assigns to each state exclusive rights over its own territory. A narrow understanding of sovereignty may fail to take into account the ways in which Indigenous and local communities' sovereignty practices - for instance, their enactment of rights with respect to making choices about the ecological futures of their environments - may be in tension or even opposition with the legal or policy norms promoted by the nation-states that claim them. ${ }^{1}$

In our reading, Hau'ofa both reflected pre-existing, and motivated emerging, ways of conceiving, perceiving, and enacting relationships between sovereignty and Indigenous peoples' and local communities' responses to the crisis of the now confronting environmental conservation, island sustainability, and natural resource management. Today, these conceptions, perceptions and practical relationships are visible in regional discourses across a variety of scales. These range from heads of state speaking in international fora such as COP23 (Bainimarama 2018) or collectively through multilateral declarations such as the 2018 Boe Declaration of the Pacific Islands Forum (Pacific Islands Forum Secretariat 2019), to culturally grounded conservation practitioners and scholars (Roberts et al. 1995; Kurashima et al. 2018). They are also expressed by everyday community members across the region contributing personal resources to projects large and small from invasive species removals, to fishpond or seaweed restorations, to managed reef and fisheries closures. This activation of community members may give rise to potent social movements assigning rights to ancestral rivers in Aotearoa/New Zealand (Morris and Ruru 2010; Muru-Lanning 2016) or blocking the exploitation of mountainscapes such as the Kia' $i$ and Aloha 'Aina centred movement in Hawai' $i$ (GoodyearKa'oppua 2017; Fujikane 2018; Case 2019; Ho'omanawanui et al. 2019). Social theorists (e.g. Latour 2004, 2018) have written more generally about global discursive shifts that emphasise the postnational or regional scale as a response to the ecological crisis. We suggest that there is something fundamentally striking about how Indigenous and local stances toward conservation and sovereignty are articulated in Oceania.
Explicit engagement with sovereignty as discussed in this article may initially be challenging to natural scientists and conservation practitioners. However, the Indigenous beliefs and practices around environmental and ecological rights located in what we are calling an Oceanian Sovereignty share much in common with scientific conservation objectives. Outlining and articulating these commonalities for both environmental scientists and Indigenous practitioners forms a major focus of this article. Such understanding is vital as a number of aspects of discourses and practices around sovereignty, including highly explicit assertions or sometimes subtle insinuations by community members may challenge or frustrate the understanding of those who are not themselves rooted in regional community/ties. The same holds true for environmental activists who are rooted in the region but not necessarily trained in the social sciences with the disciplinary tools useful in articulating cultural, social, and political dimensions with ecological or conservation dimensions towards policy and governance. In that gaps in understanding between positionalities increase the chance of poor outcomes, we identify the utility of close engagement with Hau'ofa's work at the intersection of environmental, ecological and human dimensions that we locate in Oceanian Sovereignty.

The need to engage with sovereignty discourses reflected in Hau'ofa is precisely what is indicated by increasingly clarion calls to mainstream the social sciences (Bennett et al. 2017). In order to better integrate human dimensions in conservation planning and enactment (Gray et al. 2017; Teel et al. 2018), practitioners must more carefully engage the nexus of beliefs and values about personhood, social collectives, and the ethics of relationship between human communities and environments, ecologies, or species, as locally perceived and experienced (Chang et al. 2019; Gon and Winter 2019). Understanding these human dimensions is critical to understanding the roles played by place-based culture (Masterson et al. 2017) and Indigenous and local values (Jones et al. 2016; Arias-Arévalo et al. 2017) in social-ecological systems towards sustainable futures. Increased attention to the dynamics of what we are identifying as Oceanian Sovereignty may be a deeply needed complement to remarkable work by conservation practitioners to engage Indigeneity, culturally sensitive, culturally grounded, and place-based dimensions of conservation work.

\section{A sea of sovereign-ties}

Famously, driving from Kona to Hilo on the island of Hawai' $i$, en route to give a talk, Tongan anthropologist Epeli Hau'ofa had a numinous 'road to Damascus' experience. The elaborate disciplinary edifices of the various social sciences that had framed Oceania and its islands and peoples as small, resource poor, disconnected, and permanently dependent on formal colonial powers and international organisations, came tumbling down. Hau'ofa replaced them with an alternative vision of Oceania in a futurepast of connectivity, stewardship of sea spaces, and resurgent pride in cultural identity. Hau'ofa's view of a new, if inherent and already present, Oceanian identity that could both organise and orient the region's peoples had two foundations - within specific

\footnotetext{
${ }^{1}$ Prinsen and Blaise (2017) provide a robust review of contemporary critiques of the concept of Westphalian sovereignty and critical analysis of alternative sovereignties relative to island states.
} 
island communities and within the region itself as materially mediated by the Ocean (Hau'ofa 1994: 148-151). Hau'ofa's fundamental vision was of a region whose policies, management, or governance would no longer be organised by outsider representations of, and claims to, superior agency over Oceania and its social or environmental futurity. This vision inspired and contributed to a rising tide of Indigenous peoples and local community centered agency that is now a fundamental component of Pacific Island identity and ecological actions.

Hau'ofa's 'Our Sea of Islands' became the most impactful work across Pacific Studies, with impacts across the disciplines. Notably, essential implications for local-to-regional scale governance and the everyday sovereignty and rights of Indigenous peoples and local communities within the region's postcolonial or non-self-governing states are woven into the warp and woof of his vision.

'Our diverse loyalties are much too strong to be erased by a regional identity and our diversity is necessary for the struggle against the homogenising forces of the global juggernaut. It is even more necessary for those of us who must focus on strengthening our ancestral cultures against seemingly overwhelming forces, to regain their lost sovereignty. This regional identity is supplementary to other identities that we already have, or will develop in the future, something that should serve to enrich our other selves' (Hau'ofa 2000: 33-34).

The double vision Hau'ofa offers - embracing diversity and the uniqueness of each cultural community as well as a collective Oceanian identity - links the autonomy, independence and selfdetermination concerns of Pacific Islanders as individual and atomised citizens of newly or aspirationally decolonised Pacific states, to citizenship in a secondary polis operating at both larger and smaller scales. This secondary affiliation, which we suggest be called an Oceanian Sovereignty, does not exclude the sovereignty of Fiji, Tonga, Vanuatu or other regional states but, rather, complements that narrower sovereignty with a broader, region-based sovereignty that was, perhaps, never lost because it was inherently inalienable.

Hinged to his transformative conception of an Oceanian identity, this alternative and supplemental Oceanian Sovereignty has practical governance implications bearing on the management of the regions' environments and ecologies. Its dynamic linkages to the wellbeing of Oceania's peoples for whom the loss of sovereignty to European, American, and later Japanese, Chilean, and Australian external powers, remains a total social fact even today. The legacies of the colonial era touch virtually every domain of social, cultural, political, economic, and environmental wellbeing, including for both those self-governing Pacific Islands states that legally decolonised between the end of World War II and the 1980s and for those many Pacific Islands territories that are still today non-self-governing.

In this broad historical context, Hau'ofa's argument centres a regional identity rooted in diversity and connectivity as the political foundation of collective rights to imagine and enact governance over common resources without erasing profound differences between island states, their societies and cultures.

'The time has come for us to wake up to our modern history as a region. We are not facing the issues of the Pacific
Century of Pacific Islands Region of bogus independence. We must develop a stronger and more independent regionalism than exists today. A new sense of the region that is our own creation, based on our perceptions of our realities, is necessary for our survival in the dawning era' (Hau'ofa 2000: 35).

Similarly, Hau'ofa focuses on individuals and their affinities rather than on the legally constituted state as the source of sovereign rights. He suggests that the state as traditionally defined in Westphalian terms (Stirk 2012) is not sufficiently positioned to cope with contemporary issues that exceed national borders, exclusive economic zones, and governance frontiers (Le Meur et al. 2018). The underlying geographical and institutional limitation of the concept of state-based sovereignty in Oceania is especially notable when it relates to the ocean.

'It is one of the great ironies of the Law of the Sea Convention, which enlarged our national boundaries, that it also extended the territorial instinct to where there was none before. Territoriality is probably the strongest spur for some of the most brutal acts of aggression and because of the resource potentials of the open sea and the ocean-bed, the water that has united subregions of Oceania in the past may become a major divisive factor in the future relationships between our countries. It is therefore essential that we ground any new regional identity in a belief in the common heritage of the sea' (Hau'ofa 2000: 39).

Hau'ofa's writing reflects a vision of a sovereignty grounded in a collective Oceanian identity for all Pacific Islands peoples and in a common heritage of the sea has subsequently come to be understood as the regional foundation for a critical view of westernisation and the belittling oppressiveness of major economic theories about small island economies and developing states. Oceania, he notes, 'is a world that we have created largely through our own efforts, and have kept vibrant, and independent of the Pacific island world of official diplomacy and neocolonial dependency' (Hau'ofa 2000: 32).

The equivalence Hau'ofa poses between Oceanic and Oceanian identity is another key aspect of how he articulates an orientation to practical governance rights. As Bevacqua (2010: 83) suggests, Hau'ofa invites us to rethink the ocean as a metaphor for an alternative sovereignty that could underpin governance, natural resource management, conservation, and sustainable development in Oceania. Hau'ofa concluded that as Oceanian peoples, 'The ocean is in us'. This shared substance mediates or is foundational to the 'we' to whom Oceanian Sovereignty belongs.

'A Pacific islands regional identity means a Pacific Islander identity. But what or who is a Pacific Islander? The issue should not arise if we consider Oceania as comprising human beings with a common heritage and commitment, rather than as members of diverse nationalities and races. Oceania refers to a world of people connected to each other ... For my part, anyone who has lived in our region and is committed to Oceania, is an Oceanian. This view opens up the possibility of expanding Oceania progressively to cover larger areas and more peoples than is possible under the term Pacific Islands Region ... We have to search for appropriate names for common identities that are more accommodating, inclusive and flexible than what we have today' (Hau'ofa 2000: 36). 
Running counter to the powerful current of ethnonationalism exerting pervasive force across the globe, Hau'ofa's 'we' is not based on an obvious principle of common and primordial ethnic, cultural, or linguistic origin. On the contrary, Hau'ofa locates the immense diversity, plurality, and distinctiveness of Oceania's cultures and languages as part of the strength of this community. He proposes an 'us' based on a historical and cultural heritage that exceeds local histories and sociocultural specificities and which persists in an environmental commons between radically distinct political communities. 'All of us in Oceania today, whether Indigenous or otherwise, can truly assert that the sea is our single common heritage' (Hau'ofa 2000: 39), he notes. And, 'It is of utmost significance for the strengthening of a regional identity to know that our region has achieved its greatest unity on threats to our common environment: the ocean' (Hau'ofa 2000: 35). Moreover, this identity rooted in and through a relationship to the Ocean itself, as a form of kinship, in part speaks to the intimately felt connectivity and responsibility towards the region's environmental futures (including both non-human and human dimensions) for the many Pacific peoples who live away from coasts. For the millions of Pacific Islanders who live in the highlands of the large islands of Melanesia, or in continental diasporic contexts of North America, Australia or Europe, this exceeds the profoundly meaningful but only partial formulation of 'cultural heritage' in the materiality of past-present-future interconnectedness.

Unlike a sovereignty delimited by state borders established through western legal regimes or the genealogical descent of particular Indigenous peoples and their communities, Hau'ofa's new paradigm of a supplemental and alternative sovereignty is fundamentally relational and Oceanian. 'Oceania refers to a world of people connected to each other' (Hau'ofa 2000: 36) with profound practical implications for rights of access, management of natural resources, governance norms around the management of rights and both extractive and non-extractive uses whether for cultural practice, pleasure, or commercial endeavour.

'Realisation of the fact that the ocean is uncontainable and pays no respect to territoriality should spur us to advance the notion based on physical reality and practices that date back to the initial settlements of Oceania - that the sea must remain open to all of us' (Hau'ofa 2000: 40).

Finally, Hau'ofa combines this change in posture from a focus on the state to that of individuals in enduring and reciprocal relationships to one another and their communities, with a new mechanism for regulating this sovereignty on another scale: 'Our most important role should be that of custodians of the ocean, and as such we must reach out to similar people elsewhere for the common task of protecting the seas for the general welfare of all living things' (Hau'ofa 2000: 40).

On one hand, this posture embraces the current pattern of the Pacific diaspora within and beyond Oceania's islands where genealogical lines flow and connect across, or fly above, sea-lanes and star paths, ancient and contemporary (Bennett 2015). On the other, it reinforces the coparticipation in this 'common task' between regional custodians and differently positioned partners. Thus, the conception of sovereignty developed in Hau' ofa focuses on the individual and his or her relationships; it is non-exclusive and integrates all those who recognise themselves within a common heritage and common responsibility with and to the ocean as having both rights and obligations towards decisionmaking around conserving and sustaining environmental and ecological presents into the future. This suggests an alternative mode of governance in which humans act in terms of guaranteeing a balance between living and non-living entities fundamentally coupled in their common heritage and common wellbeing.

\section{Implications of Oceanian Sovereignty towards conservation futures}

The increasing threats of climate change, environmental degradation, and biodiversity loss confronting Oceania are challenging the regions' peoples to respond with dynamic tidal thinking as never before - by tidal thinking we mean the articulation, negotiation, and enactment of ways of perceiving, conceiving, experiencing, and responding to the challenges confronting the wellbeing of the region's future across human and environmental and ecological domains. We describe these responses as dynamic tidal thinking because of the need to find ways to centre and focalise specific Indigenous ways of being and conceiving (Tengan and Roy 2014; Wilson-Hokowhitu 2019) within the intersectional spaces of conservation science, policy, and practice. Both environmental threat and necessary response are all pervasive and ever present on all shores, like ocean tides, yet touch communities in distinct ways that require dynamic and fluid responses. While the articulation of the problems presented by the changing circumstances of sea level rise, ocean plasticisation and acidification, coastal erosion, and ecological fragmentation and degradation are advancing, there has been less progress in articulating a reconceptualisation of conservation and sustainable governance of natural resources to meet these changes. However, a tidal current of thought is evident in words of regional leaders such as Cook Islands Prime Minister Henry Puna in his 2013 call for conferring legal protections and rights upon the great ocean, or Palauan President Tommy Remengesau's call for collective consciousness and action in 2014 when receiving the Champion of the Earth award from the United Nations Environmental Program. It is also evident in the strident communications of activist groups working towards environmental protections across the region such as 350 Pacific's Pacific Climate Warriors initiative, or Kua 'āina Ulu 'Auamo, a grassroots network supporting communities around Hawai'i to increase their effectiveness in managing local biocultural heritage, and everyday community members all over Oceania.

Hau'ofa's vision - particularly what we identify as his conception of an Oceanian Sovereignty - is so far the best characterisation and explanation of this alternate foundation for and orientation to shifts evident in tidal thinking around marine and terrestrial governance, natural resource management, and conservation towards sustainable island futures in Oceania. Rooted in reciprocal relations, diversity, and fluid geographic connectivity, and focused on individuals and everyday practices, the dynamic of Oceanian Sovereignty suggests a number of fundamental implications for governance bearing on conservation practice.

1. Hau 'ofa's formulation suggests that the Ocean possesses ontologically founded rights distinct from those granted by state or suprastate political institutions that impose responsibilities or even duties on individuals, communities, and states alike.

Hau'ofa's Oceanian Sovereignty is not formulated in terms of individual or collective rights on the basis of being human - as 
in a biblical lens asserting human dominion over nature - or on the basis of incorporation within a particular political state that bestows rights through governance institutions within particular legal frameworks. Rather, it is formulated in terms of responsibilities to the ocean, hence nature more broadly, as an ontological other which projects its own rights (see Bignall et al. 2016 for a comparable discussion of relational responsibility in the context of Indigenous Australia). Throughout Oceania, rights and responsibilities are obtained through the reciprocal relationships maintained between human entities, non-human living entities, and environmental or ecological place (Gaspar and Bambridge 2008). In turn, the processual identity created by the relationship between the ocean, human individuals and collectives, and 'all living things' within Oceania's environments undergirds the rights and responsibilities associated with Oceanian Sovereignty - for instance, the fundamental coupling of rights of access and duties to stewardship of resources. While state-based sovereignty is typically defined through rights to self-determination, an Oceanian Sovereignty is centred in responsibility established with respect to the ocean and its plurality of inclusive entities. For Hau'ofa, to be Oceanian is to be accountable for acts and practices that could cause harm to an other that has an inherent, ontologically founded, right not to be harmed. The recently enacted Palau Pledge is an exceptional example of this at the state level (www.palaupledge.com), as are the grounded articulations of the $\mathrm{Ku} \mathrm{Kia}$ 'i Mauna community activists as stewards responsible for the spiritual and material wellbeing of Mauna Kea (Goodyear-Ka‘ōpua 2017).

One final implication of this point: the ocean is not only a subject of law but is a producer of law and a partner in the constitution of this emergent-if-pre-existing regional sovereignty. Enactments of legal personhood over Ocean spaces or many conservation domains or natural resources comparable to the establishment of legal personhood for Awa Tupuna in Aotearoa (Ruru 2018) have not yet been legislated by regional states or international fora (Barcan 2019). However, within Hau'ofa's vision, the Ocean has already always been a partner or coactor to its own and its peoples' futurity and wellbeing. The implications for conservationists are that effective enactment and enforcement requires local participation and consideration of multiple and overlapping conservation and ethical regimes hinged to local salient ontologies of nature.

2. The social identity or 'we' associated with Oceanian Sovereignty is not exclusive, nor closed, but appears as a processual identity that is created in and through reciprocal relationships to the Ocean as partners or coactors in political processes, as opposed to subjects of or subjects to political processes of particular states.

In Hau'ofa's vision of an equivalence in which an Oceanian identity in an oceanic identity, he indexes a number of environmental themes, related to fisheries or pollution, that call for the responsibility of Pacific Islanders. Moreover, he notes, contemporary environmental and ecological crises, largely resulting from the activities of former or continuing colonial states and their post-Industrial revolution projects, are fundamentally connected to prior environmental and ecological crises created and enacted by, generally speaking, those very same states. For instance, Hau'ofa argues that: 'The movement toward a Nuclear Free and Independent Pacific, the protests against the wall-of-death drift netting, against plans to dispose of nuclear waste in the ocean, the incineration of chemical weapons on Johnston Island, and the 1995 resumption of nuclear tests on Mururoa, and most ominously, the spectre of our atoll islands and low-lying coastal regions disappearing under the rising sealevel, are instances of a regional united front against threats to our environment. ... The problems, especially of toxic waste disposal and destructive exploitation of ocean resources, still remain to haunt us. Nuclear powered ships and vessels carrying radioactive materials still ply the ocean; international business concerns are still looking for islands for the disposal of toxic industrial wastes; activities that contribute to the depletion of the ozone still continue; drift netting has abated but not stopped, and the reefs of the Mururoa atoll may still crack and release radioactive materials.' (Hau'ofa 2000: 35)

A vision of Oceanian Sovereignty implies the presence of the past and a history of prior linked historical environmental and social traumas and the responsibility to respond to them. As also founded on duties and obligations, this is something conservation scientists can become part of, for instance by recognising generations of guardianship as ongoing and active, and the need to be, in turn, recognised by local communities. For conservation practice, this emphasis on duties rather that rights, is congruent with recent decades' changing paradigm. For instance, where the Convention for Biological Diversity identifies local communities' sovereign rights to agency over local natures including genetic resources in their environments, one might perceive a recognition of the duty those communities may experience to make decisions about those resources, species, and ecologies based on culturally grounded understandings of the rights of the Ocean, and its species and ecologies, within a fundamentally non-binary relationship to human domains. Through the lens of Oceanian Sovereignty, it is not the state that ratifies Indigenous peoples and local communities' rights to exert agency over the region's ecological futures but their ongoing relational responsibility to the Ocean and its regional natures when perceived, conceived, and engaged as partners in futurity.

Hau'ofa's epistemological revolution develops sovereignty from relationality rather than political and legal constitutional developments. Oceanian Sovereignty thus inscribes sovereignty in the everyday enactments of rights of engagement, reciprocal and relational, between individuals, communities, and island environments and ecologies as opposed to the enactments of states and their necessarily 'elitist and westernised' institutions of governance. This epistemological revolution in sovereignty questions has another methodological implication. Instead of assuming what sovereignty is in Westphalian terms and asking individuals or communities to weigh in on and respond to how well the state is or is not addressing their needs, it implies that rights to exert agency over local natures rise from the ground up. Specifically, it asserts that rights emerge from Indigenous and local communities and will frequently exceed national borders to connect partners in a sea of islands (Hau'ofa 1994:160).

Oceanian Sovereignty suggests that governance or management action be perceived, conceived and engaged as a common enactment between partners, including the region's diverse communities at regional scale, that may overlap with, but not be defined by, the state or international governance framework whose agents and agencies are already well known. Hau'ofa 
writes that 'Acting in unison for larger purposes and for the benefit of the wider community could help us to become more open-minded, idealistic, altruistic and generous, less selfabsorbed and corrupt, in the conduct of our public affairs than we are today' (Hau'ofa 2000: 33). For conservation scientists, policy makers, or practitioners to take such a stance would, in this view, constitute a corrective mechanism.

One of the most delicate issues confronting any governance or management context is the establishment of who can determine environmental and ecological futures and make decisions (Mawyer and Jacka 2018). Oceanian Sovereignty implies that all who foster, maintain, and express this reciprocal-relationship are, or could be, part of this Oceanian 'we' sharing the reciprocal burden of collective responsibilities that emerge from the place-basedness of the region's Indigenous peoples and local communities. Finally, historically, Oceania is considered as the common heritage of its inhabitants (D'Arcy 2006). Thus conceived, Oceania is not a territorialised space, a fortiori defined by the national boundaries of colonial and postcolonial states including high-seas and exclusive economic zones, but as a place of Indigenous agency that implies common responsibilities refracted through the lens of culturally grounded ethics. Conservation actions would thus benefit not only from taking into account but, perhaps, beginning with the ethics of relationship and obligation as understood, experienced and practiced by Indigenous peoples and their communities.

3. In term of governance, Oceanian Sovereignty implies a 'hybrid commons' with the Ocean as a political partner. All human individuals, their collectivities, and their states and agencies, are equally bound by the obligations of stewardship, custodianship, respect and responsibility towards Ocean as self and as partner.

One problem confronting ocean governance and policy making, including between states and suprastate institutions, is that the ocean can be considered as a tangible resource that risks being overexploited, or with respect to which users do not pay sufficient attention to their sustainable use (Bambridge et al. 2019). One might reflect, here, on the tragedy of the commons (Hardin 1968) in which people, or institutions, can be predicted to behave opportunistically, such as stowaways or freeriders, and consider as free-forthe-taking the resources they access without the possibility of exclusion. For example, because the fish does not belong to anyone, a fisherman will tend to catch all the fish he can, helping to reduce the resource without worrying about its preservation or the sustainability of its exploitation. Individuals pursuing their private goals produce disastrous consequences for themselves and for others. Criticising Hardin, Ostrom (1990) demonstrates that within communities, non-market, non-public policy rules and institutions can emerge to ensure sustainable and shared management of resources, as well as efficient management from an economic point of view. However, from the perspective of a region saturated in Oceanian sovereignties, it should be clear that a plurality of collectivities bearing different cultural-commitments, practices, juridical or political frameworks, are exerting normative governance and visions of sustainability and futurity over marine spaces and their resources. Beyond its political and legal aspects, we hypothesise that the governance framework adapted to this new form of sovereignty is a 'hybrid common', a concept that we develop following Ostrom (1990) and Dietz et al. (2003). Oceanian
Sovereignty implies thinking carefully about the culturally grounded, place-specific and region-specific ways in the which norms and regularities supporting sustainability, and the rights and responsibilities regimes that support them, are operating in Oceania.

Sensitivity to the presence of an Oceanian Sovereignty within the region's communities should remind conservation practitioners that, across Oceania, Indigenous and local cultural norms, protocols, and rights regimes hinged to sustainability have long been in place and remain operative alongside, if often overshadowed by, the legal regimes established in the wake of settler colonial projects in the region. As the title of Elinor Ostrom's Nobel Lecture 'Beyond Markets and States: Polycentric Governance of Complex Economic Systems' recalls, the reality of multiple and complementary (and not strictly alternative) levels must be taken into account. Thus, the governance or conservation of Oceania's resources that emerges from state or suprastate actors should actively seek to engage with and benefit from other modes of governance and the legal pluralisms (Bambridge 2016) that emerge and exert normative force from Indigenous peoples and local communities' Oceanian Sovereignties.

4. User boundaries for engagement with Ocean must be crisply defined and locally understood by legitimate users and non-users. With regard to the ocean, clear boundaries specifically separate common pool resources from a wider socio-ecological system.

Recognising the presence of Oceanian identity and Oceanian Sovereignty which it grounds, makes it possible to distinguish a community whose ocean constitutes at the same time a cultural, historical, and economic heritage in contrast to other regional or international actors, state and non-state, who 'covet Oceania' (Bennett et al. 2015; Al Wardi et al. 2017). A double challenge therefore arises to recognise Oceanian Sovereignty in Hau'ofa's sense: to integrate state and non-state actors within the same body and to ensure that mechanisms exist to solve the problems of asymmetry of power and equity. For conservation scientists, policy makers, or practitioners, the material point here is that conservation itself is a kind of resource exploitation - where the resource in question is the right to choose ecological futures. Even when defined as for the wellbeing of all, varied priorities and views of nature mean that conservation actions impose the same sorts of boundary negotiations as other kinds of resource engagements, whether extractive or sustainable, and are thus incipient with a range of possible contestations and conflicts.

The geographical imagination of the region, including Oceania's Asian and American boundaries is also in critical need of attention. We note that in many conservation and sustainable futures discourses around the Pacific Islands and Oceania, Asian and pre-Columbian traditions, which have an ancestral and coastal culture, are excluded from many regional scale deliberations about environmental or ecological futures in 'Oceania'. However, the construction of a commons on an oceanic scale requires taking into account the various regimes of the law of the sea set up by the Montego Bay Convention in 1982 and the integration of all actors in an expanded region. The highly unsatisfactory results in seeking sustainable fish catches based on voluntary compliance regimes in the high seas suggest such an expanded regime based on Oceanian principles of relationality merits support from within scientific conservation advocates and practitioners. The Oceanian principle that we argue both produces effective local management and best 
finds common cause with global allies is the idea of rights of access and oversight based on the ongoing enactment of responsibilities rather than intrinsic rights as the most likely path to a minimisation of harm and maximisation of benefits to both human communities and their entangled local natures.

5. Oceanians are the appropriate users of Ocean and should control the levels of exploitation and extraction of regional resources and the legal provisions thereunto. Similarly, the monitoring or control of resources should also be exercised by Oceanian communities as the centred responsible parties.

The logic of collective action postulated by Hau'ofa involves a variety of actors. The appearance of mainstream sites such as 'Global Fish Watch', supported by international non-government organisations, now simultaneously inform all sorts of actors of the fishing activity in the region. Similarly, the monitoring of resource exploitation activities across the Pacific cannot be done without the cooperation of the so-called great powers already present in the region (notably the USA, New Zealand, Australia and France). The challenge is to allow a transparent flow of governance authority including the information necessary for policy determinations to Indigenous and regional stakeholders who share in Oceanian Sovereignty. While this will seem supplemental from the point of view of the western state, this Oceanian recentring should result in more democratic and efficacious decision making towards collective wellbeing. Hau'ofa emphasises this perspective when he notes that 'We have floundered, also, because we have considered regionalism mainly from the point of view of individual national interests rather than those of a wider collectivity; and we have failed to build any clear and enduring regional identity because we have continued to construct edifices with disconnected traits from traditional cultures and passing events, without basing them on concrete foundations' (Hau'ofa 2000: 43). Hence, people affected by a resource plan must be supported to participate in its development and subsequent amendments. This point is clearly posited by Hau'ofa through his vision of a collective identity mediated through and by the ocean. Most states in Oceania now include a wide variety of stakeholders in the management committees that manage the marine areas in their large exclusive economic zones. This mechanism could be extended to all areas of the high seas in the Pacific, with necessary adjustments.

\section{Conclusion: oceanic futures and Indigenous futurity}

Successfully transforming conservation practice to adequately address the presence and potential of Oceanian Sovereignty in the region will require attention not only to knowledges about nature, but also to nuanced and complex Indigenous political histories and contemporary dynamics. A sea change in understanding will require conservation scientists, policy makers, and practitioners to extend their political sensitivities beyond the geopolitics of Westphalian sovereignty represented by the UN, various suprastate fora, and the enactments of particular nation-states within their exclusive economic zones and national borders. Accounting for the presence of an Oceanian Sovereignty rising from the wellspring of local communities and being articulated by Pacific Islander heads of state from the top-down and by community actors from the ground-up is a missing dynamic in many conventional conservation approaches, both conceptually and practically. Meanwhile, the tidal thinking in which Oceanian
Sovereignty is expressed vis à vis Oceania's environments and ecologies is actively framing and constituting tomorrow's conservation contexts and dynamics for the region's peoples.

The rising tide of Oceanian Sovereignty needs to be understood by all who seek better conservation outcomes. It is a better representation of the underlying realities of multiple levels of conservation action, including the plurality of overlapping enforcement regimes, than purely state-centred analysis. Conservation biologists share many of the same objectives of Oceania's Indigenous peoples and their communities, and the latter's underlying beliefs and emphasis on respect for nature and access based on Oceanian principles of relationality - the enactment of responsibilities rather than intrinsic rights - also share much in common. Hau'ofa's vision of a broad and inclusive community of common interest and shared action rather than exclusive membership offers a path forward to the broad-based coalitions of community support needed to convert scientific advocacy into political action and local agency.

In closing, we want to draw attention to two final observations from Hau'ofa: one spatial and one temporal. Hau'ofa advocated for the efficacy of moving towards regional, collective action when he noted that 'Acting together as a region, for the interests of the region as a whole, and above those of our individual countries, we would enhance our chances of survival in the century that is already dawning upon us' (Hau'ofa 2000: 33). He went on to observe that 'We must develop a stronger and more independent regionalism than exists today. A new sense of the region that is our own creation, based on our perceptions of our realities, is necessary for our survival in the dawning era' (Hau'ofa 2000: 35). A key feature of an Oceanian Sovereignty is the way that it draws on an Indigenous futurity - a regional future that has not foreclosed the agency and continuity of the regions' Indigenous peoples despite the erosions of settler colonial histories, globalisation, or neoliberal capital. Critically, at the same time, this vision brings the stakes of addressing environmental and ecological governance and natural resource management in the present into view in a manner that encompasses the past and the future for all who acknowledge responsibilities to the ocean regardless of their heritage. The deep time and place of Oceania's peoples and their culturally rich ecological knowledge and practice includes both a relationship to the past and a profound relationship to the future as articulated by Hau'ofa, prefiguring a key insight that policy, governance, resource management and conservation are about everyday ethics of practice towards a deep future.

\section{Conflicts of interest}

The authors declare no conflicts of interest.

\section{Acknowledgements}

This research did not receive any specific funding. We are grateful to three reviewers of an earlier draft of this work and to the editors of this special issue for thoughtful, generous insights.

\section{References}

Aburto, J. A., Gaymer, C. F., and Govan, H. (2020). A large-scale marine protected area for the Sea of Rapa Nui: from ocean grabbing to legitimacy. Ocean \& Coastal Management 198, 105327. doi:10.1016/ J.OCECOAMAN.2020.105327 
Al Wardi, S., Regnault, J.-M., and Sabouret, J.-F. (2017). 'L'Océanie Convoitée: Histoire, Géopolitique et Sociétés.' (Edition du CNRS: Paris.)

Alegado, R. (2019). Opponents of the thirty meter telescope fight the process, not science. Nature 572, 7-8. doi:10.1038/D41586-01902304-1

Arias-Arévalo, P., Martín-López, B., and Gómez-Baggethun, E. (2017). Exploring intrinsic, instrumental, and relational values for sustainable management of social-ecological systems. Ecology and Society 22, 43. doi:10.5751/ES-09812-220443

Bainimarama, F. (2018). We Need Talanoa for Climate Ambition - COP 23 President. Available at https://unfccc.int/news/we-need-talanoa-forclimate-ambition-cop-23-president.

Bambridge, T. Ed. (2016). 'The Rahui: Legal pluralism in Polynesian Traditional Management of Resources and Territories.' (ANU Press: Canberra.)

Bambridge T, Gaulme F., Montet C., and Paulais T. (2019). 'Communs et Ocean. Le Rāhui en Polynésie’. (Editions Au Vent des Iles, Agence Francaise du Développement: Papeete, Tahiti.)

Barcan, R. (2019). The campaign for legal personhood for the Great Barrier Reef: finding political and pedagogical value in a spectacular failure of care. Environment and Planning E: Nature and Space 3, 810-832. doi: $10.1177 / 2514848619886975$

Bennett, J. Ed. (2015). 'Oceanian Journeys and Sojourns: Home Thoughts Abroad.' (Otago University Press: Dunedin.)

Bennett, N. J., Govan, H., and Satterfield, T. (2015). Ocean grabbing. Marine Policy 57, 61-68. doi:10.1016/J.MARPOL.2015.03.026

Bennett, N. J., Roth, R., Klain, S. C., Chan, K. M., Clark, D. A., Cullman, G., Epstein, G., Nelson, M. P., Stedman, R., Teel, T. L., and Thomas, R. E. (2017). Mainstreaming the social sciences in conservation. Conservation Biology 31, 56-66. doi:10.1111/COBI.12788

Bennett, N. J., Blythe, J., Cisneros-Montemayor, A. M., Singh, G. G., and Sumaila, U. R. (2019). Just transformations to sustainability. Sustainability 11, 3881. doi:10.3390/SU11143881

Berkes, F. (2017). 'Sacred Ecology.' (Routledge: New York.)

Bevacqua, M. L. (2010). Our Sea of Islands: Epeli Hau'ofa and Frantz Fanon. LiNQ 37, 80-93.

Bignall, S., Hemming, S., and Rigney, D. (2016). Three ecosophies for the Anthropocene: environmental governance, continental posthumanism and indigenous expressivism. Deleuze Studies 10, 455-478. doi:10.3366/DLS.2016.0239

Case, E. (2019). I ka Piko, to the summit: resistance from the mountain to the sea. The Journal of Pacific History 54, 166-181. doi:10.1080/00223344. 2019.1577132

Chang, K., Winter, K. B., and Lincoln, N. K. (2019). Hawai'i in focus: navigating pathways in global biocultural leadership. Sustainability 11, 283. doi: $10.3390 / \mathrm{SU} 11010283$

Dacks, R., Ticktin, T., Mawyer, A., Caillon, S., Claudet, J., Fabre, P., Jupiter, S. D., McCarter, J., Mejia, M., Pascua, P. A., and Sterling, E. (2019). Developing biocultural indicators for resource management. Conservation Science and Practice 1, e38. doi:10.1111/CSP2.38

Dietz, T., Ostrom, E., and Stern, P. C. (2003). The struggle to govern the commons. Science 302, 1907. doi:10.1126/SCIENCE. 1091015

D'Arcy, P. (2006). 'The People of the Sea: Environment, Identity, and History in Oceania.' (University of Hawaii Press: Honolulu.)

D'Arcy, P. (2009). Variable rights and diminishing control: the evolution of indigenous maritime sovereignty in Oceania. In 'Water, Sovereignty and Borders in Asia and Oceania'. (Eds D. Ghosh, H. Goodall, and S. H. Donald.) pp. 34-51. (Routledge: New York.)

Fujikane, C. (2018). Mapping abundance on Mauna a Wākea as a practice of Ea. Hülili: Multidisciplinary Research on Hawaiian Well-Being 11, 23-54.

Gaspar, C., and Bambridge, T. (2008). Protected territories and marine areas in Moorea (French Polynesia). Journal de la Société des Océanistes $\mathbf{1}$, 231-246. doi:10.4000/JSO.2462

Gon, S. O., and Winter, K. B. (2019). A Hawaiian renaissance that could save the world: this archipelago's society before Western Contact developed a large, self-sufficient population, yet imposed a remarkably small ecological footprint. American Scientist 107, 232. doi:10.1511/2019. 107.4.232

Goodyear-Ka' $\mathrm{o} p u a$, N. (2017). Protectors of the future, not protestors of the past: Indigenous Pacific activism and Mauna a Wākea. South Atlantic Quarterly 116, 184-194. doi:10.1215/00382876-3749603

Gray, N. J., Bennett, N. J., Day, J. C., Gruby, R. L., Wilhelm, T. A., and Christie, P. (2017). Human dimensions of large-scale marine protected areas: advancing research and practice. Coastal Management 45, 407-415. doi:10.1080/08920753.2017.1373448

Halpern, B. S. (2020). Building on a decade of the Ocean Health Index. One Earth 2, 30-33. doi:10.1016/J.ONEEAR.2019.12.011

Hardin, G. (1968). The tragedy of the commons. Science 162, 1243-1248. doi:10.1126/SCIENCE.162.3859.1243

Hau'ofa, E. (1994). Our sea of islands. The Contemporary Pacific: A Journal of Island Affairs 6, 148-161.

Hau'ofa, E. (2000). The ocean in us. In 'Culture and Sustainable Development in the Pacific'. (Ed. A. Hooper.) pp. 32-43. (Australian National University Press: Canberra.)

Ho'omanawanui, K., Fujikane, C., Kagawa-Viviani, A., Kamakaoka'ilima Long, K., and Perry, K. (2019). Teaching for Maunakea: Kia 'i perspectives. Amerasia Journal 45, 271-276. doi:10.1080/00447471.2019.1686318

Jones, N. A., Shaw, S., Ross, H., Witt, K., and Pinner, B. (2016). The study of human values in understanding and managing social-ecological systems. Ecology and Society 21. doi:10.5751/ES-07977-210115

Kelman, I. (2017). How can island communities deal with environmental hazards and hazard drivers, including climate change? Environmental Conservation 44, 244-253. doi:10.1017/S0376892917000042

Keppel, G., Morrison, C., Watling, D., Tuiwawa, M. V., and Rounds, I. A. (2012). Conservation in tropical Pacific island countries: why most current approaches are failing. Conservation Letters 5, 256-265. doi:10.1111/J.1755-263X.2012.00243.X

Kurashima, N., Jeremiah, J., Whitehead, A. N., Tulchin, J., Browning, M., and Duarte, T. (2018). 'Āina Kaumaha: the maintenance of ancestral principles for 21 st century indigenous resource management. Sustainability 10, 3975. doi:10.3390/SU10113975

Latour, B. (2004). 'Politics of Nature.' (Harvard University Press: Cambridge, MA.)

Latour, B. (2018). 'Down to Earth: Politics in the New Climactic Regime.' (Polity Press: Cambridge.)

Lauer, M. (2017). Changing understandings of local knowledge in island environments. Environmental Conservation 44, 336-347. doi:10.1017/ S0376892917000303

Le Meur, P.Y., Bambridge, T., Degremont, M., and Rodary, E. (2018). Les espaces marins du Pacifique entre logiques de communs et d'accaparement. Revue internationale des Études du Développement 234,9-30. doi:10.3917/ RIED.234.0009

Leenhardt, P., Cazalet, B., Salvat, B., Claudet, J., and Feral, F. (2013). The rise of large-scale marine protected areas: conservation or geopolitics? Ocean \& Coastal Management 85, 112-118. doi:10.1016/J.OCECOAMAN.2013. 08.013

Leong, K. M., Wongbusarakum, S., Ingram, R. J., Mawyer, A., and Poe, M. (2019). Improving representation of human well-being and cultural importance in conceptualizing the West Hawai'i ecosystem. Frontiers in Marine Science 6, 231. doi:10.3389/FMARS.2019.00231

Lyver, P. O. B., Ruru, J., Scott, N., Tylianakis, J. M., Arnold, J., Malinen, S. K., Bataille, C. Y., Herse, M. R., Jones, C. J., Gormley, A. M., and Peltzer, D. A. (2019). Building biocultural approaches into AotearoaNew Zealand's conservation future. Journal of the Royal Society of New Zealand 49, 394-411. doi:10.1080/03036758.2018.1539405

Masterson, V. A., Stedman, R. C., Enqvist, J., Tengö, M., Giusti, M., Wahl, D., and Svedin, U. (2017). The contribution of sense of place to social-ecological systems research: a review and research agenda. Ecology and Society 22, 49. doi:10.5751/ES-08872-220149 
Mawyer, A., and Jacka, J. K. (2018). Sovereignty, conservation and island ecological futures. Environmental Conservation 45, 238-251. doi:10.1017/ S037689291800019X

McMillen, H. L., Ticktin, T., Friedlander, A., Jupiter, S. D., Thaman, R., Campbell, J., Veitayaki, J., Giambelluca, T., Nihmei, S., Rupeni, E., and Apis-Overhoff, L. (2014). Small islands, valuable insights: systems of customary resource use and resilience to climate change in the Pacific. Ecology and Society 19, 44. doi:10.5751/ES-06937-190444

Morishige, K., Andrade, P., Pascua, P., Steward, K., Cadiz, E., Kapono, L. and Chong, U. (2018). Nā Kilo 'Āina: visions of biocultural restoration through Indigenous relationships between people and place. Sustainability 10, 3368. doi: $10.3390 /$ SU10103368

Morris, J. D., and Ruru, J. (2010). Giving voice to rivers: legal personality as a vehicle for recognising Indigenous Peoples' relationships to water? Australian Indigenous Law Review 14, 49-62.

Muru-Lanning, M. (2016). 'Tupuna Awa: people and politics of the Waikato River.' (Auckland University Press: Auckland.)

Ostrom E. (1990). 'Governing the Commons: The Evolution of Institutions for Collective Action.' (Cambridge University Press: Cambridge.)

Pacific Islands Forum Secretariat. (2019). BOE Declaration Action Plan. Available at https://www.forumsec.org/wp-content/uploads/2019/10/ BOE-document-Action-Plan.pdf

Pascua, P. A., McMillen, H., Ticktin, T., Vaughan, M., and Winter, K. B. (2017). Beyond services: a process and framework to incorporate cultural, genealogical, place-based, and indigenous relationships in ecosystem service assessments. Ecosystem Services 26, 465-475. doi:10.1016/J.ECOSER.2017.03.012

Prinsen, G., and Blaise, S. (2017). An emerging "Islandian" sovereignty of non-self-governing islands. International Journal 72, 56-78. doi: $10.1177 / 0020702017693260$
Roberts, M., Norman, W., Minhinnick, N., Wihongi, D., and Kirkwood, C. (1995). Kaitiakitanga: Maori perspectives on conservation. Pacific Conservation Biology 2, 7-20. doi:10.1071/PC950007

Ruru, J. (2008). A Maori right to own and manage national parks? Journal of South Pacific Law 12, 105-9.

Ruru, J. (2018). Listening to Papatūānuku: a call to reform water law. Journal of the Royal Society of New Zealand 48, 215-224. doi:10.1080/ 03036758.2018.1442358

Russell, J. C., and Kueffer, C. (2019). Island biodiversity in the Anthropocene. Annual Review of Environment and Resources 44, 31-60. doi:10.1146/ANNUREV-ENVIRON-101718-033245

Stirk, P. M. R. (2012). The Westphalian model and sovereign equality. Review of International Studies 38, 644. doi:10.1017/S0260210511000192

Teel, T. L., Anderson, C. B., Burgman, M. A., Cinner, J., Clark, D., Estévez, R. A., Jones, J. P., McClanahan, T. R., Reed, M. S., Sandbrook, C., and St John, F. A. (2018). Publishing social science research in conservation biology to move beyond biology. Conservation Biology 32, 6-8. doi:10.1111/COBI.13059

Tengan, T., and Roy, L. M. (2014). 'I Search for the Channel Made Fragrant by the Maile': genealogies of discontent and hope. Oceania 84, 315-330. doi:10.1002/OCEA.5067

Wilson-Hokowhitu, N., ed. (2019). 'The Past Before Us: Mo'okū'auhau as Methodology.' (University of Hawai 'i Press: Honolulu.)

Wittmer, H. U., Anton, V., Gruber, M. A., Ireland, L., Linklater, W., Russell, J. C., and Shanahan, D. F. (2018). Conservation and restoration in peopled landscapes in Oceania: opportunities and challenges. Pacific Conservation Biology 24, 409-416. doi:10.1071/PC18072 